\section{A importância do helenismo no pensamento do Apóstolo Paulo*}

\section{Isidoro Mazzarolo ${ }^{a}$}

Pontifícia Universidade Católica do Rio Grande do Sul, Brasil http://orcid.org/0000-0001-9620-1517

RECEBIDO: 05-04-18. APROVADO: 03-08-18

Resumo: Paulo foi um homem de três culturas e "três cabeças". Ele assimila elementos importantes do ambiente grego, do judeu e do romano. Paulo mostra-se mais do que um apóstolo; revela-se um grande mestre das mentes e coraçóes. $\mathrm{Na}$ missão dentro do mundo greco-romano, ele faz uso de muitos elementos da cultura helenística, a fim de alcançar seus objetivos evangelizadores. Este artigo pretende realçar a importância da linguagem, dos conceitos e outros elementos da cultura grecoromana na teologia e antropologia paulina.

Palavras-chave: O apóstolo Paulo; helenismo; cristianismo; cultura greco-romana.
The Importance of Hellenism in the Thought of Apostle Paul

AвSTRACT: Paul was a man of three cultures and "three heads." He assimilates important elements of the Greek, the Jewish and the Roman environments. Paul appears to be more than an apostle; he reveals himself to be a great master of minds and hearts. In his mission into the Greco-Roman world, he uses many elements of the Hellenistic culture in order to achieve his evangelizing goals. This article intends to highlight the importance of language, concepts and other elements of Greek-Roman culture in the Pauline theology and anthropology.

Key Words: The Apostle Paul; Hellenism; Christianity; Greco-Roman culture.

\section{Cómo CITAR:}

Mazzarolo, Isidoro. "A importância do helenismo no pensamento do Apóstolo Paulo". Theologica Xaveriana 188 (2019): 1-24. https://doi.org/10.11144/javeriana. tx69-188.ihpap

* Artigo de investigação

${ }^{a}$ Autor de correspondencia. Correio eletrônico: mazzarolo.isidoro@gmail.com 


\section{Apresentação}

Paulo de Tarso é o homem de três mundos, três culturas, três cabeças (judeu, grego, romano) e, concernente à religião: um só Deus e um só Espírito (1Cor 12,1-12), ou, "um só Senhor, uma só fé, um só batismo, um só Deus e Pai de todos, o qual é sobre todos, age por meio de todos e está em todos" (Ef 4,5-6)1.

A base filosófica de Paulo é fortemente helenística. Os princípios de autonomia, liberdade e criatividade revelaram um homem de uma inteligência espiritual superior ou um coeficiente espiritual elevado. Pode-se afirmar que, enquanto jovem judeu, vivendo sua infância e juventude em Tarso, Paulo se nutre de duas fontes: a fonte da cultura greco-romana e a fonte da religiosidade judaica.

A vida no ambiente de Tarso, cidade muito helenizada, transformou o ambiente familiar do jovem Paulo (Saulo). O pai adquiriu a cidadania romana para fazer frente à realidade de modo mais seguro e, consequentemente, Saulo herdou da família essa abertura para a cultura ocidental. Saulo (Paulo) é cidadão romano de nascimento (At $16,37-38 ; 22,25-29 ; 23,27)$ e, esse documento de identidade lhe era muito útil para o trânsito dentro do Império e em situaçóes complicadas com tribunais das cidades por onde passava, como em Filipos (At 16,16-24), em Corinto (At 18,12-17) e em Jerusalém (At 22,25).

O contato com culturas e religiosidades múltiplas fez desabrochar em Paulo uma espiritualidade que transcendia a razão e a graça que superava a Lei. Inserido no ambiente greco-romano, preocupa-se com a $p a z$, visto que a paz verdadeira náo existia, como já estava publicada na crítica profética $(\mathrm{Jr} 6,14 ; 8,11 ; 30,5 ; \mathrm{Ez} 13,10 ; 16)^{2}$. A preocupação do Apóstolo era com a paz do coração e do encontro com o outro. Sua infância em Tarso lhe foi muito útil e o levou a aprender a liberdade, a filosofia e a convivência pacífica com culturas diversas e crenças bem variadas. Essa experiência de vida fora de sua pátria, no entanto, foi, em grande parte, sufocada no seu retorno a Jerusalém.

Paulo vive em Tarso, nos tempos do imperador Augusto, quando Roma chamava o Mediterrâneo de Mare Nostrum. Passou sua infância em Tarso como cidadão com plenos direitos e pertencia a uma das grandes famílias hebraicas da cidade,

\footnotetext{
${ }^{1}$ Benoit, "Genese et évolution de la pensée paulinienne", 96. A autenticidade de Efésios é bastante discutida, mas há autores que aceitam a carta como autêntica do Apóstolo, como é o caso de P. Benoit. Benoit argumenta que a Carta pode incluir relatos do redator, como acréscimos pessoais, mas o pensamento e muitos traços da carta aparecem como autêntico ditado. Ele ainda faz uma análise da evolução do pensamento paulino, partindo da primeira Carta aos Tessalonicenses até Efésios.

${ }^{2}$ Penna, "L’Evangile de la paix", 178.
} 
emigrada para lá nos tempos de Antíoco Epífanes (seu reinado durou de 175 a 164 a.C., aproximadamente) $)^{3}$.

Essa informação pode ser questionada, se levarmos em conta a tese de MurphyO'Connor, fundamentado na afirmação de São Jerônimo sobre seu nascimento na Gishala, que Jerônimo localiza na Judeia, mas ela seria uma cidade da Galileia. ${ }^{4}$ Por outro lado, na Carta aos Filipenses (Fl 3,5), Paulo afirma que era da tribo de Benjamim, enquanto no relato de Lucas afirma que nasceu em Tarso, da Cilícia (At 9, 11; 21,39; $22,3 ; 23,34)$. Permanece a discussão sobre quando a família de Paulo se transferiu da Palestina para Tarso, se foi quando houve a perseguição de Antíoco Epífanes ou mais tarde.

Ao decidir estudar de modo mais profundo as tradiçôes de seus antepassados, dirigiu-se a Jerusalém e colocou-se aos pés do grande mestre Gamaliel (At 22,3). Nessa escola, conformou-se aos costumes do ambiente judaico. Por essa razão, sentia-se impelido a combater os cristãos, os quais eram considerados hereges (At 8,1-3; Lv 20,8-27). A morte de Estêváo (At 7,58-8,1) e a visão de Jesus ressuscitado no caminho para Damasco fizeram com que recuperasse os princípios filosóficos gregos, numa volta psicológica e antropológica aos tempos de jovem, em Tarso.

Ele sabia que, num universo plural e politeísta, como era o dos gregos, não se matava por questóes de religiáo e, diante da conduta dos seus compatriotas contra os cristáos, Paulo reflete sobre esta conduta. E, enquanto se dirigia a Damasco, com cartas das autoridades de Jerusalém, ouviu uma voz e viu uma luz. A voz que escutou era ade Cristo sendo perseguido por ele (At 9,5).

Essa visão, uma autêntica cristofania, o fez perceber a necessidade de olhar a realidade de modo diferente, e a experiência de Tarso começa a ser recuperada. Assim, no caminho para Damasco, ele encontrou o Cristo do caminho, que, depois de se apresentar como o perseguido, transformou o perseguidor em discípulo. Foi aqui que Paulo encontrou novamente a liberdade que o levou para a fé verdadeira $(G 15,1)$. Nessa ótica, o Cristo do caminho aproximou Paulo outra vez do helenismo e o levou a relativizar o radicalismo do judaísmo $(\mathrm{Fl} 3,8)$. Associando critérios estoicos

${ }^{3}$ Turbessi, “L’Apôtre Paul, 'Homme de Dieu”, 106.

${ }^{4}$ Murphy-O'Connor, Jesus e Paulo, vidas paralelas, 28. O autor, pautado em referências de São Jerônimo, sustenta que Paulo (Saulo) teria nascido na Gishala. Segundo Jerônimo, a Gishala era uma pequena Vila da tribo de Benjamim, na Judeia, no entanto, ela era uma cidade da Galileia. Essa diferença pode estar no conceito de Judeia que Jerônimo tinha na época. A família teria mudado para Tarso em busca de condiçôes de vida melhores, quando Saulo era ainda criança e lá cresceu e viveu até ir para Jerusalém, a fim de estudar aos pés de Gamaliel (At 22,3; 26,4-5). Essa é a razão pela qual era chamado Saulo de Tarso e não da Gishala, pois tinha sido conhecido como um jovem de Tarso (At 22,3). Essa afirmaçáo de Jerônimo ainda é muito discutida e incerta. 
e epicuristas de felicidade aos ensinamentos cristãos, Paulo parte para buscar as coisas do alto e construir a cidadania celeste $(\mathrm{Fl} 3,2)$, transformando as relaçóes terrestres a exemplo do Mestre (Fl 2,1-11).

\section{Helenismo e suas manifestações na religiosidade de Paulo}

\section{Introdução}

Para entender a envergadura do pensamento e da teologia de Paulo é necessário fazer um percurso dentro das linhas gerais do helenismo. A força e o prestígio da democracia ateniense tornaram o grego uma língua comum. Já no IV século a. C. o rei da Macedônia, Felipe II estabeleceu o grego como a língua da administração e da diplomacias

Uma razoável compreensão do helenismo nos permite, ao menos em parte, imergir no universo da obra do Apóstolo, destacando os elementos de sintonia do cristianismo com a cultura grega. Em dois de seus relatos autobiográficos, Paulo afirma que nasceu em Tarso, na Cilícia, uma das cidades principais da regiâo oeste da Ásia Menor (Fl 3,3-5; At 22,3-5). Conforme algumas pesquisas mais recentes, Saulo Paulo ${ }^{6}$ pode ter nascido na Judeia ou Galileia e, ainda criança, foi para Tarso com a família.

Mesmo sendo filho de judeus da tribo de Benjamim (Fl 3,5-7), a família de Paulo foi fortemente influenciada pela cultura helenística de Tarso, o que lhe possibilitou interagir com os princípios do helenismo e do romanismo (At 16,21.37; 22,25). Essa formação pluricultural permitiu a Paulo a abertura e o trânsito, como cristão, nos ambientes regidos pelo politeísmo da cultura greco-romana. A flexibilidade, adaptação e a inculturação do Evangelho foram, ao menos em grande parte, frutos dessa convivência com o helenismo.

A primeira experiência forte do encontro do cristianismo com o helenismo se deu na Antioquia da Síria (hoje pertence à Turquia), e foi lá que os seguidores de Jesus foram chamados, pela primeira vez, de cristãos (At 11,26). A benevolência e a tolerância marcavam a conduta alicerçada na fé e no amor, mais do que em discursos teóricos ou no legalismo judaico.

\footnotetext{
${ }^{5}$ Hadjifoti, Apóstol Pablo: su vida y su obra, 14.

${ }^{6}$ Odelain e Séguineau, "Paul, Paulus", 289-291. Os autores afirmam que Paulo (Paulus) era o sobrenome romano de Saoul. Lucas, no texto dos Atos dos Apóstolos, nomeia-o Saulo (At 7,58-13,9). Em At 13,9 faz a passagem: "Saulo, também chamado Paulo...", e segue depois com Paulo até o final do livro, exceto nos dois discursos de Paulo 22,7.13 (diante dos judeus de Jerusalém); 26,14 (diante de Agripa), quando ele narra sua vocação.
}

${ }^{7}$ Turbessi, "L’Apôtre Paul, 'Homme de Dieu’”, 138. 
Paulo, depois do encontro com o Senhor, no caminho para Damasco (At 9,1-9), não negou o judaísmo, mas se afastou muito, por razóes éticas, visto que o judaísmo conservador tinha problemas de convivência com o diferente, com o estrangeiro, com a mulher, o doente e o desconhecido. Por isso, o Apóstolo aproximou-se do helenismo em virtude de ser mais aberto e politizado. Jesus superou os paradigmas judaicos de tratamento do doente, do estrangeiro, da mulher, do impuro e do samaritano, criados como mecanismos de exclusão no pós-exílio (por volta de 450 a. C.).

Paulo, depois de sua conversão, recuperou os elementos de sua juventude no universo helenista e seguiu o exemplo concreto de Jesus, afirmando que não deveria haver mais discriminação de gênero, posição social ou de raça (Gl 3,28). Quando, no entanto, se refere às leis, escritas e inscritas no coração ( $\mathrm{Rm} 7,1-12$, por exemplo) ele está se aproximando do estilo retórico do filósofo e orador romano Cícero: "Há sem dúvida, Juízes, esta lei, não escrita, mas congênita, que não aprendemos, ouvimos ou lemos, mas participamos, bebemos e tomamos da mesma natureza, na qual não fomos ensinados, mas formados, nem instruídos, mas criados".

Referenciais externos, como esta do orador Cícero, são muito importantes na teologia e antropologia paulina. Os judeus rejeitavam os pagãos por serem impuros, e os gregos rejeitavam os citas por considerá-los ignorantes e incultos. Para Cícero, pela lei natural, que absorvemos desde a infância, não podemos justificar discriminaçôes. A polis abrigava gente de muitas culturas, raças e condiçóes sociais diferentes. Os gregos não marginalizavam os provenientes de outros lugares, mas assimilavam seus paradigmas como somatórios ao próprio ambiente. Assim acontecia na sociedade, na cultura e na língua.

Paulo, como judeu helenista, utilizou muitos elementos da linguagem grega para dialogar com eles nos campos da retórica, da religiosidade e da filosofia. Os judeus queriam sinais, e os gregos, sabedoria (1Cor 1,22). Uma novidade, mesmo que fosse de um "tagarela", era sempre interessante (At 17,18).

A linguagem e muitas imagens da comunicação paulina revelam uma grande proximidade com o helenismo e suas formas de vida quotidiana nas cidades, esportes, educação e outros. Encontram-se muitos vocábulos que não possuem correspondência no hebraico e, por isso, ressoam como exclusiva influência helenística, tais como egkráteia - "autocontrole" (Gl 5,23), assim como o verbo egkrateúomai - "exercitar o auto-controle" (1Cor 7,9; 9,25); euschêmosynê - "decoro" (1Cor 12,23) e também os derivados em Rm 13,13; 1 Cor 7,35; 12,24; 14,40; 1Ts 4,12; o substantivo paidagôgós - "pedagogo" (1Cor 4,15; Gl 3,24-25), parousía - "vinda do Senhor”, usado por Paulo

\footnotetext{
${ }^{8}$ Cicero, Oraçóes, 6.
} 
tanto para definir o sentido histórico-biográfico (1Cor 16,17; 2Cor 7,6.7; 10,10; Fl 1,$26 ; 2,12$ ) quanto no sentido cristológico-escatológico (1Cor 15,23; 1Ts 2,19; 3,13; 4,15; 5,23); politeuma - "cidadania" (Fl 3,20, com o verbo politeúesthai - "tornarse cidadão" (Fl 1,27), prokopê - "progresso" (Fl 1,12.25), syneidêsis - "consciência, entendimento" ( $\mathrm{Rm} \mathrm{2,15;} \mathrm{9,1;} \mathrm{13,5;} \mathrm{1Cor} \mathrm{8,7.10.12;} \mathrm{10,25.27.28.29;} \mathrm{2Cor} \mathrm{1,12;}$ 4,2; 5,11; cf. 1Cor 4,4) .

Uma particularidade paulina é o uso do lexema huouthesía = "filiação" ( $\operatorname{Rm} 8,15.23 ; 9,4 ; \mathrm{Gl} 4,5)$. O termo, além de ausente na LXX, não aparece em qualquer outro lugar da literatura judaica antiga, inclusive em Josefo e Fílon. Segundo a pesquisa de Walters, evidentemente não é um termo que Paulo tomou das fontes judaicas. Sem dúvida, Josefo e Filon e outros judeus da diáspora estavam familiarizados com a adoção. No entanto, a huouthesía não aparece no mundo judaico, porque uma pessoa não podia ser introduzida numa família judia para continuar a linhagem do adotante. Os judeus cuidavam das crianças órfẫs, mas esse cuidado visava habitualmente os membros sobreviventes da família, sem qualquer procedimento formal de adoção (cf. Est 2,7.15) ${ }^{10}$.

O testemunho mais antigo da legislação de adoção e herança no mundo grego é do século VI a. C., e, uma reformulação atualizada foi feita por Demóstenes no século IV a. C. Nesses dois documentos, um possuidor de patrimônio, que não tivesse filhos homens e estivesse em condiçóes de saúde mental sadia, tinha direito de adotar qualquer outro e conferir-lhe o direito de herança ${ }^{11}$. Vê-se, nesse particular, como Paulo pode ter usado arquétipos jurídicos helenísticos para falar do compromisso e da responsabilidade da administração da graça, da vocação e da missão, como herança cristá. O cristão foi adotado por Cristo, pois o pecado de Adão teria originado essa perda de filiação (Rm 5,12; 8,14-17).

No mundo grego era muito comum uso da linguagem esportiva, com metáfora para na educação, associando os desafios dos atletas com os desafios da vida de qualquer pessoa. "A sociedade helenística antiga era completamente agonística12, isto é, altamente competitiva"13. O atletismo era uma atividade preparatória para as competiçôes de modo análogo ao da preparação para o exército, atividades associadas

\footnotetext{
9 Penna, "Paulo de Tarso e os componentes gregos do seu pensamento", 58.

${ }^{10}$ Walters, "Paulo, a adoção e a herança”, 26.

${ }^{11}$ Ibid., 28.

${ }^{12}$ Bauer, "Agôn", 28-29. O termo agôn significa luta, peleja, batalha militar. Esse termo foi aplicado aos jogos e ao treinamento dos atletas, pois cada jogo é como se fosse uma batalha para um soldado.

${ }^{13}$ Krentz, "Paulo, os jogos e a milícia", 304.
} 
com frequência. Os discursos motivadores para os atletas diante de uma competição e os dos generais aos militares numa situação de conflito eram semelhantes: precisava lutar para vencer ${ }^{14}$. Nas batalhas, os generais lutavam junto com seus soldados, servindo-lhes de apoio e encorajamento.

Paulo colocava-se sempre adiante dos cristãos que evangelizava, pedindo que eles fossem seus coimitadores de Jesus Cristo ("symmimêtai mou ginesthe", Fl 3,17) e utilizava discursos convincentes e persuasivos a fim de que os cristáos não sucumbissem diante dos sofrimentos (Fl 2,1-17).

Os pensadores éticos utilizavam com frequência a imagem do estádio como metáfora da vida: era preciso moldar a personalidade, fortalecer o caráter e crescer na virtude (arêtê) como a mesma disciplina dos atletas. Paulo também faz uso dessa metáfora (1Cor 9,24-27) exatamente aos Coríntios, ótimos conhecedores dos jogos pan-helenísticos ${ }^{15}$. Ele, no entanto, usa um vocabulário teológico próprio quando associa as imagens do estádio, da competição e do atleta à vida cristã. Ele insere essa linguagem "competitiva" num campo de reflexão própria para indicar as sensaçôes, situações e provaçóes de um cristão.

Quer na apologese com os judeus de Filipos ( $\mathrm{Fl} 2,16)$, quer na autodefesa diante dos "notáveis" da Igreja de Jerusalém (Gl 2,2), o Apóstolo recorre à linguagem esportiva para associá-la ao processo de anúncio do Evangelho. Ele quer ter a certeza e a segurança de "não correr ou ter corrido em vão" (Fl 2,16; Gl 2,2). Anunciar o evangelho não era uma questão de orgulho, mas um imperativo (1Cor 9,16). Por isso era como uma competição num estádio: precisava ter estímulos e preparo para vencer.

A compreensão do ambiente da competição projetada nas perspectivas teológicas evoca nos seus leitores uma reflexão muito importante para não encarar a vida como predestinaçáo, como determinada a priori e sem responsabilidade para o leitor ou ouvinte. A vida não está numa câmara hermética, não está enclausurada em um conjunto de prescriçôes fatídicas a cumprir ou num pré-determinismo irrevogável. A vida é como um jogo num estádio: é preciso lutar, pois só recebe a coroa quem vencer (1Cor 9,23).

O apóstolo dos gentios quer que os cristãos, no testemunho do Evangelho, se pareçam ou tenham a mesma consciência de quem vai entrar num estádio para competir. A vida é uma competição, é uma luta e tem de ter objetivos e metas bem definidos para quem quer vencer. Se só vencem os melhores, então os cristãos se preparem para lutar juntos numa só alma pela fé no Evangelho (Fl 1,27; 4,3).

${ }^{14}$ Ibid., 307.
${ }^{15}$ Ibid., 316. 
$\mathrm{Na}$ linguagem esportiva, o termo sôtêr era dado ao vencedor. Na mitologia dos cultos imperiais, esse título era usurpado pelos imperadores aplicando para si, características próprias das grandes divindades como Isis, Zeus e outros ${ }^{16}$.

Paulo não usa literalmente o termo sôtêr, mas o substantivo sôtêria (salvação). $\mathrm{Na}$ apologese paulina percebe-se uma construção com a linguagem pagá, mas com uma deslocação de acento e conteúdo. A salvação não vem do imperador, mas de Deus que perdoa e resgata o mundo dos seus pecados (Rm 1,16;10,1;11,1;13,11). Nessa construção retórica, Paulo também combate a mitologia e a idolatria e o culto aos imperadores.

Ainda dentro da linguagem apologética observa-se o aproveitamento exemplar da linguagem esportiva aplicada ao evangelho e à vida cristã. Os gregos valorizavam muito as competiçóes como forma de estimular o desenvolvimento integral da pessoa. Nessa perspectiva, muitos vocábulos esportivos usados pelos gregos são aplicados por Paulo concernente ao anúncio do Evangelho: agôn - "combate, luta" (Fl 1,30; 1Ts 2,2); com o verbo agônizomai - "entrar na peleja" (1Cor 9,25); brabeîon - "prêmio" (1Cor 9,24; Fl3,14); pykteú̂ - "desferir socos" (1Cor 9,26); stádion - "estádio” (1Cor 9,24); stéfanos - "coroa” (1Cor 9,25; Fl 4,1; 1Ts 2,19); synathléô - "lutar junto, combater junto" (Fl 1,27; 4,3); trechô - "correr" (Rm 9,16; 1Cor 9,24.26; Gl 2,2; 5,7; Fl $2,16)^{17}$. O substantivo agôn (luta, peleja), o verbo brabeúesthai (receber prêmio, $\mathrm{Sb}$ 10,12) e o lexema stádion - "estádio" (1Cor 9,24-27) têm o significado de medida e objetivos ou metas, como metáfora da competiçấo e da necessidade da "luta" para superar os obstáculos: "Não sabeis que, no estádio, todos correm, mas um só leva o prêmio? Correi a fim de que o alcanceis" (1Cor 9,24).

\section{Alguns traços do helenismo na antropologia de Paulo}

Paulo absorve muitos elementos de cultura greco-romana desde o seu berço, guarda-os na bagagem e tira-os no momento oportuno. Não se sabe até que nível de escolaridade Paulo chegou. Em Gl 6,11 diz que está escrevendo com letras grandes e de próprio punho. Ele tinha sempre presente a conceituação grega da arêtê e do cosmopolitismo, conceitos oriundos da Acaia e aprimorados na Macedônia, nos séculos VI e V a. C. Segundo Corssen ${ }^{18}$, o helenismo marca a história com conceitos como cosmopolitismo, individualismo, realismo e teocracia ${ }^{19}$.

\footnotetext{
${ }^{16}$ Bauer, "Sôtêr", 1585.

${ }^{17}$ Penna, "Paulo de Tarso e os componentes gregos do seu pensamento", 58.

${ }^{18}$ Corssen, "Über Begriff und Wesen des Hellenismus", 83.

${ }^{19}$ Muitos autores, especialmente exegetas, preferem falar em monolatria em lugar de monoteísmo. Acreditam que as tentativas de cultuar um Deus único, não obstante pareça uma opção monoteísta, é considerada de modo mais corretamente interpretada como uma postura monolátrica.
} 
1. $\mathrm{O}$ cosmopolitismo era entendido como o acesso à cidadania pelas pessoas cultas, aquelas iniciadas nas letras e nas ciências. Por isso, os gregos não separavam nacionais e estrangeiros, mas ignorantes e letrados. Mesmo sendo estrangeiro, todo aquele (homem ou mulher) que fosse possuidor de desenvolvimento intelectual, conhecimentos e erudição era considerado cidadão (cosmopolita = cidadão do mundo, sem distinção de fronteiras geográficas).

Esse conceito influenciou de modo direto a postura antropológica de Paulo, mas ele não coloca o acento na instrução ou conhecimento, como era próprio dos gregos, mas no amor e na pedagogia de Cristo (Gl 3,28; $\mathrm{Rm} \mathrm{10,12;} \mathrm{Cl} 3,11)$. No pensamento de Paulo, esse cosmopolitismo derruba todos os arquétipos excludentes entre classes sociais, culturas, línguas ou fronteiras, especialmente as criadas pelo judaísmo pós-exílico (Esd 9-10).

A aproximação das culturas e raças está na comparação que ele faz entre Adão e Jesus (1Cor 15,22). Nesse texto, Paulo afirma que todos morrem em Adão, isto é, todos são formados do barro, do húmus terrestre. Por isso são matéria transitória, mas todos serão vivificados em Cristo. Todos os nascidos de Adão se assemelham quanto à natureza, origem e lugar de proveniência. Por essa razão, o cosmos é a pátria dos filhos de Adão, enquanto o céu é a pátria de todos, em Cristo ( $\mathrm{Fl} 3,20)$. O Adão terrestre, moldado do barro, é feito da alma vivente, do sopro de Deus sobre o barro, mas o Adão celeste (o último Adão) é feito do espírito vivificante, que promove a vida no cosmos (1Cor 15,45; Rm 5,12-21) ${ }^{20}$.

2. O individualismo era a marca da ética helenística. O provérbio "conhece-te a ti mesmo" apontava para a necessidade de cada indivíduo conhecer suas capacidades e potencialidades a fim de "se virar na vida". Ao escrever aos Coríntios, Paulo cita uma máxima por eles manifestada: "Tudo me é permitido" (1Cor 6.12), mas ele imediatamente corrige e acrescenta: "Mas nem tudo me convém". Jesus usa esse princípio na parábola do administrador infiel (Lc 16,1-8). Nas questóes econômicas percebemos a inspiração helenística nas orientaçôes sobre a dignidade de cada operário receber seu salário (Lc 10,7; 1Cor 9,9; 1Tm 5,18).

3. O realismo era um princípio criado por Sócrates, mas desenvolvido por Platão e seus discípulos, em que o mais importante era o real, o definitivo, que eles chamavam também de "ideal”. Para essas correntes filosóficas, as coisas que passam não têm muita importância; o que interessa é o "eterno", o "definitivo" e o transcendente. A gnôsis desempenhou um papel importante e, ao mesmo tempo, ambíguo, mostrando que os indivíduos, ao alcançarem o "conhecimento", estariam entrando em esferas

\footnotetext{
${ }^{20}$ Mazzarolo, Carta de Paulo aos Romanos. Educar para a maturidade e o amor, 83.
} 
superiores, destacando-se dos demais. O real e a sombra são explicitados no mito da caverna de Platão.

Esse realismo, na estrutura mental de Paulo, corresponde a uma verdadeira maturidade na fé e na justiça. O ser humano real é a sua alma que se torna verdadeira quando ele alcança sua maturidade e sua perfeição ou acabamento do ser integral, na teleiosis (1Cor 13,10; 14,20; Fl 3,15; Cl 4,12). Paulo integra os conceitos judaicos ensinados por Jesus (ex: Mt 7,19-21) aos ensinamentos gregos das realidades superiores como sendo definitivas diante das coisas desse mundo que passam e as aplica no seu método de evangelização. O ser humano está a caminho da sua perfeição e seu acabamento. Por isso, seu mundo real é o ideal, que é também o eterno (Ef 2,19), e sua cidadania (politeuma) está nos céus (Fl 3,20).

Nessa perspectiva da cidadania celeste talvez possamos ver uma influência da paideia grega sobre a escatologia em Paulo. Para o Apóstolo, a escatologia não é algo nos céus a ser recebida ou esperada no fim dos tempos, mas algo já realizado no mundo com a vinda de Jesus Cristo. $\mathrm{O}$ triunfo da vida sobre a morte não é futuro, mas já presente para todos os batizados em Cristo ${ }^{21}$.

4. A teocracia era a postura que justificava a interferência direta das divindades sobre os humanos e sobre o cosmos. Percebe-se facilmente um movimento integrador e globalizante: a filosofia, a cultura, a estética, a mitologia, a arte e a política estão dentro de uma mesma esfera: a polis (cidade).

Para os platônicos, regidos pelo mito da caverna de Platáo, a esfera transcendente passa a ter maior importância que a esfera imanente, uma vez que nela está o real, enquanto no universo físico está a sombra. O Deus criador (da tradição do Antigo Testamento) passa a ser compreendido como o Lógos, por Heráclito, a realidade pura e perfeita, mas não é o único, pois no Panteon, esse Deus, criador e absoluto na tradição judaico-cristâ, vai disputar um lugar com os outros deuses (At 17,16-34). É a sabedoria de Pitágoras, Anaxágoras e Platão que irrompe criando um novo universo conceitual e virtual.

Por outro lado, como afirma von Dobschütz ${ }^{22}$, a inteligência humana é desafiada a resolver seus enigmas por duas vias: a primeira é de modo racional; a segunda é pela inspiração divina.

No raciocínio do Apóstolo, a soberania de Deus, invisivel, e desconhecido dos filósofos (At 17,23-24) torna-se visível na pessoa de Jesus Cristo (Ef 1,3-6; Cl 1, 15-20). É essa busca pela novidade que, depois de ouvir falar dos prodígios que Jesus

\footnotetext{
${ }^{21}$ Benoit, "Genese et évolution de la pensée paulinienne”, 97.

${ }^{22}$ Von Dubschütz, "Christianity and Hellenism”, 246.
} 
realizava, alguns gregos que estavam na Palestina se dirigem a Filipe e lhe suplicam: "Queremos ver Jesus" (Jo 12,20).

Nessa mesma pista do Deus absoluto, Paulo, bom conhecedor dos esquemas teosóficos greco-romanos e de Zeus como o grande pai dos povos pagãos, propóe o Deus de Jesus Cristo como o Abbá! Pai (Rm 8,14-17; Gl 4,4-7). Aos poucos, o esquema grego da filiação de Zeus passa para a filiação ao Deus de Jesus Cristo como Deus supremo e único.

\section{Paulo e a relação do cristianismo com o helenismo}

No encontro com o helenismo, o cristianismo precisa fazer adaptaçóes e, para isso, a capacidade intelectual dos evangelizadores da "primeira hora" soube inculturar sua linguagem e mensagem. Os helenistas esperavam e desejavam novidades. $\mathrm{O}$ evento Jesus Cristo lhes interessava, mas a resposta dos cristáos vinha numa direção que os surpreendia, pelo fato de vir de fora das esferas do saber deles. Ouvir sobre um outro deus, o Deus desconhecido, imutável, intangível, todo poderoso, era um encantamento aos olhos e uma provocação à inteligência, mas quando Paulo começou falar do Messias com a Cruz, aquilo que era expectativa e interesse passou a ser paradoxo e contradição.

A linguagem da cruz, aos ouvidos dos filósofos, era "loucura", mas Paulo explica: "loucura é para aqueles que se perdem, enquanto para os que se salvam é poder de Deus" (1Cor 1,18). Ampliando o "escândalo", o Apóstolo continuou dizendo: Nós anunciamos o Cristo crucificado, que para os judeus é escândalo e para os gentios (grecoromanos) é loucura (1Cor 1,23). Em vez de ser uma satisfação às buscas individuais e das soluçóes próprias, apregoadas no helenismo, o cristianismo propóe um compromisso mútuo e solidário, quer na esfera material, quer na esfera espiritual (1Cor 12,1-12). A solução de tudo parte no imperativo de criar comunidades, famílias que integram línguas, culturas e raças diferentes. Os estoicos sustentavam uma linha de pensamento que ensinava a cada indivíduo esquecer a própria história e tradição e começar por si e para si.

O helenismo sofria influência das cosmogonias e da religiosidade egípcia e iraniana, dado que ele vai incorporar à sua constelação mitológica divindades dos povos conquistados. Esse processo de assimilação vai ocasionar a metamorfose das divindades. No caso de Cibele, a Magna Mater da Frígia e a deusa por excelência da natureza e mãe dos deuses, difundida especialmente nas regióes do mar Egeu, vai tomar o lugar de Ártemis, mais tarde, em Éfeso ${ }^{23}$. Da mesma forma com Ísis do Egito, que vai passar para a Grécia e depois para Roma com o nome de Ártemis e depois Diana.

\footnotetext{
${ }^{23}$ Kittel, Die Religionsgeschichte und das Urchristentum, 27.
} 
Esse movimento de adaptação de cultos e transformação de nomes é chamado por muitos pesquisadores de metamorfose $e^{24}$. Isso mostra uma dinâmica pluricultural na adaptação das suas formas e conceitos religiosos. A religiáo não se separa da cultura, pois a religião é cultura e tradição.

Paulo conhecia bem os lugares por onde andava e, ao mesmo tempo em que assumia muitos elementos importantes das culturas locais, sabendo combater aquilo que considerava erro ou prejuízos para o Evangelho. Ele entabulava um diálogo firme com o helenismo e a gnose, mas sabia também orientar os cristãos a distinguir os erros dessas filosofias ${ }^{25}$. $\mathrm{Na}$ Carta aos Colossenses, especialmente no Capítulo 2, percebe-se que os cristãos professavam sua fé em Cristo.

No entanto, alguns grupos acreditavam também nas cortes dos anjos, os quais controlavam os elementos do mundo e, esses deviam ser pacificados através de ritos. A arte desses ritos era de raiz gnóstica. Paulo afirmava que os que seguiam essas filosofias não negavam, propriamente, a Cristo, mas ele os exorta à necessidade de crer somente nele, pois ele é a plenitude da divindade $(\mathrm{Cl} 2,9)$.

\section{As cosmogonias}

Nas cosmogonias (sistemas possíveis da formação e origem do universo) da literatura helenística, o Lógos tem um papel importante, mas seu pai é Hermes. O Lógos e Hermes foram enviados por Zeus ${ }^{26}$ para criar o mundo. Hermes corresponde ao egípcio Thot. Nessa interligação de divindades e conceitos religiosos (uma metamorfose), pode-se elaborar uma pergunta: No bojo da formação da doutrina do Lógos, no helenismo e em Fílon, não está uma influência da teosofia egípcia?

Numa análise dessa literatura, Bill afirma que ela faz parte de um vasto corpo de escritos místico-mitológicos que têm uma expressão cosmogônica, teológica e religiosa $^{27}$. Essa literatura hermética de Poimandres deve ter influenciado alguns traços da teologia cristã. Num caso específico, o Pastor de Hermas, na sua visão principal,

\footnotetext{
${ }^{24}$ Delcourt, Legendes et cultes de héros en Grèce, 18.

${ }^{25}$ Grech, "L'Inno cristologico di Col 1 e la gnose", 87.

${ }^{26}$ É o organizador do mundo interior e exterior. Segundo Mircea Elíade (Elit,77), é o arquétipo do chefe de família patriarcal, com sua esposa Hera, governa desde o Olimpo. "A concepção de Zeus como divindade suprema e como força universal desenvolveu-se a partir dos poemas homéricos e chegou, entre os filósofos helenísticos, à concepção de uma Providência única. Entre os estoicos [...], Zeus é o símbolo do Deus único que encarna o cosmos" (Chevalier e Gheerbrant, Dicionário de símbolos: mitos, sonhos, costumes, gestos, formas, figuras, cores, numeros, 478).

${ }^{27}$ Bill, "La littérature religieuse hellénistique et les religions des mystères d'après Reitzenstein", 446.
} 
refere-se muito a Poimandres. Nisto podemos concluir que a fonte de Poimandres e do profeta cristão é a mesma (questão da metamorfose dos símbolos) ${ }^{28}$.

\section{As religiôes mistéricas e o mistério de Cristo}

O politeísmo grego era benéfico à "nova religião" (cristianismo) enquanto não fechava portas ou fronteiras às novidades. Contudo, oferecia algumas dificuldades quando se tratava de chegar a um ponto comum: o monoteísmo cristão. As chamadas religióes mistéricas estavam impregnadas de mitos, ritos e esoterismos. As divindades Zeus e Hera, uma espécie de metamorfose dos deuses egípcios Ísis e Osíris, presentes também na gnôsis, tinham como características ser divindades da libertação e remissão das situaçôes ruins e enchiam de graça seus redimidos.

Quando o cristianismo nasce e começa sua expansão pelo mundo greco-romano, vai defrontar-se com a força dessa religiosidade mitológica. De modo particular, Paulo e seus colaboradores se aventuram com muita segurança no âmago dessa religiosidade, utilizando essa linguagem, até certo ponto, fechada ou criptografada: o mistério. Paulo usa uma linguagem helenística para explicar que Jesus Cristo é o mistério de Deus no qual estão escondidos os tesouros da sabedoria e do conhecimento $(\mathrm{Cl} 2,2-3)$.

A linguagem mistérica era própria da gnôsis e reservada aos iniciados no conhecimento e sabedoria das coisas "ocultas". Em Cristo está a plenitude do conhecimento e do entendimento, razão pela qual Paulo insiste que os cristãos de Roma não ignorem esse mistério e enrijeçam seus coraçóes $(\mathrm{Rm} 11,25)$. Esse mistério estava escondido desde os tempos eternos ( $\mathrm{Rm}$ 16,25). Assim como se estivesse falando a iniciados nas religióes mistéricas, Paulo afirma que ele vai apresentar a Sabedoria de Deus, oculta em mistério, a qual Deus ordenou desde antes dos séculos para a nossa glória (1Cor 2,7).

A grande novidade na teologia de Paulo, em relação aos esquemas filosóficos gregos, é que, enquanto nos esquemas teosóficos greco-romanos os mistérios continuavam escondidos, no cristianismo esse mistério escondido desde antes dos séculos, agora, foi revelado em Cristo Jesus, com toda a plenitude do conhecimento e da sabedoria $(\mathrm{Gl} 4,4)$. Essa posição servia para instar os cristáos desses ambientes a acreditar no cristianismo e asseverar de que não havia mais razão para serem induzidos por vãs filosofias e especulaçôes mentais ${ }^{29}$. Paulo faz uso dessa linguagem repetidas vezes, mostrando de modo suave, mas apologético, a superação dos arquétipos antigos do

\footnotetext{
${ }^{28}$ Betz, Hellenismus und Urchristentum, 61.

${ }^{29}$ Mazzarolo, Colossenses: Exegese e comentário, 69-72.
} 
"ocultismo" aos iniciados e que Jesus Cristo, como mistério escondido, já não está mais escondido, mas sim revelado ${ }^{30}$.

Nos cultos mistéricos, os que eram iniciados, participavam da realidade da divindade, para isso realizavam-se três passos: (a) o rito de purificação; (b) a relação de comunhão com a divindade; c. a promessa de felicidade ${ }^{31}$. Essa comunhão com a divindade, a partir da Ceia de Cristo, é explicitada aos Coríntios para combater os ritos de banquetes idolátricos, os quais conferiam essa comunhão com os deuses (1Cor 10,14-22).

\section{Esquemas filosófico-antropológicos helenísticos e Paulo}

A gnôsis's

A gnôsis está sempre ligada ao conhecimento, reconhecimento e sabedoria. Nos aspectos bíblicos refere-se muitas vezes ao conhecimento de Deus $(\mathrm{Sl} 18,2 ; \mathrm{Sb} 2,13)$ ou à salvação (Lc 1,77; 2Cor 10,5) ${ }^{33}$. O lexema aparece sessenta e oito vezes no Novo Testamento, nas diferentes formas e funçóes. $\mathrm{O}$ conhecimento pode ser abstrato quando se reduz à mera especulação intelectual ${ }^{34}$. $\mathrm{O}$ conhecimento de Deus implicava diretamente na prática dos mandamentos (Os 4,1-4). Paulo fala não só do conhecimento, mas também do reconhecimento dos decretos de Deus ( $R m$ 2,18); da lei divina $(R m 7,1)$, não como pura teoria, mas na obediência e na prática $(\mathrm{Rm} 2,20)^{35}$.

No quando da visão macrocósmica, o ser humano está aprisionado neste mundo e fica a mercê do relacionamento com "o deus desconhecido", isto é, o profundo e ignoto relacionamento com o mundo superior ${ }^{36}$. Esse "deus desconhecido" poderia indicar um contexto das religiôes mistéricas ou, ao menos lendária, mas também recebia o culto no Areópago de Atenas (At 17,23).

${ }^{30}$ Ver Rm 11,25; 16,25; 1 Cor 2,1.7; 4,1; 13,2; 14,2; 15,51; Ef 1,9; 3,3.4.9; 3,32; 6,19; Cl 1,26.27; 2,2/4,3; 2Ts 2,7 .

${ }^{31}$ Tripolitis, Religions of the Hellenistic-Roman Age, 17.

${ }^{32}$ Do ponto de vista da história, a gnôsis pertence ao mundo grego, por volta do V século a. C.; do ponto de vista da práxis religiosa e sociológica, pode ser caracterizada como algo presente em todas as religióes e sociedades, desde os tempos mais remotos até nossos dias. Toda a religiáo ou rito religioso desvinculado da práxis é vazio e, no sentido puro, pode ser considerado mero conhecimento ou abstração. O verdadeiro conhecimento de Deus move o crente a uma conduta coerente com essa sabedoria.

${ }^{33}$ Bauer, "Gnôsis", 324.

${ }^{34}$ Lalande, "Gnose", 448.

35 Schmitz, "Conhecimento", 399.

${ }^{36}$ Rudolph, La gnosi, 142. 
No campo antropológico, a gnôsis é um sistema filosófico-religioso que preconiza diferenças sociais, culturais e religiosas entre os seres humanos, de acordo com seu nível de conhecimento e desenvolvimento intelectual. No âmbito teológico encontra-se uma massiva insistência sobre os princípios da criação e a figura de Adão e Eva, mesmo com fundamentações em textos extrabíblicos ${ }^{37}$.

Um postulado bastante forte é que através do conhecimento e da especulação intelectual é possível atingir esferas (estratos) superiores. Isso garante privilégios e assegura melhor posição do indivíduo diante do seu próximo e diante de Deus. Gnôsis significa conhecimento. Esse sistema sustentou muitas correntes de pensamento, ideologias políticas e estruturas religiosas. Os gregos ambicionavam a "transcendência" através da razão ou do intelecto. Os judeus almejavam a salvação através da prática dos preceitos da tradição e da Torá.

Paulo, no entanto, combate essas correntes anunciando o Cristo crucificado como caminho de integração desses esquemas excludentes, mesmo que para os judeus fosse escândalo e para os gentios loucura, mas para os que são chamados, tanto judeus como gregos, Cristo é o poder de Deus e sabedoria de Deus (1Cor 1,23-24).

Utilizando uma analogia de origem egipcia, nos cultos a Isis e Osiris, mas com grande difusão no mundo grego, Paulo mostra que a força de Cristo está na sua semelhança com Deus ${ }^{38}$. "Para combater ou converter os cristáos desses ritos ao cristianismo, o Apóstolo afirma que o "homem... é a imagem de Deus (1Cor 11,7) e, o "homem novo" é à imagem do seu Criador $(\mathrm{Cl} 3,10)$. De modo análogo em $\mathrm{Rm}$ 8,29 , fala daqueles que são "predestinados a ser conforme à imagem do Filho dele"; conforme 2Cor 3,18, "nós seremos transformados à imagem do Senhor ressuscitado"; e, segundo 1Cor 15,49, "seremos transformados na imagem do homem celeste", isto é, de Cristo glorioso" ${ }^{39}$.

Paulo aproveita muitos filóes da gnôsis para aplicar suas novas linhas querigmáticas. Ele distingue o homem sárkiko ou sômátiko (1Cor 3,3; Rm 1,26-27; 7,4; $\mathrm{Cl} 2$,9) do pneumático ou "espiritual' (1Cor 2,13; 9,11; Ef 6,12). O homem físico ou somático pode representar o judeu apegado à Lei e o pagão apegado aos ídolos; o homem espiritual configura o judeu livre da Lei $(\mathrm{Gl} 5,1)$ e o pagão liberto dos ídolos (cf. 1Cor 8,7-10). Enquanto dependente da sárx o ser humano fica vinculado aos rudimentos desse mundo, que ele chama de stoicheîa tou kosmôे (Gl 4,3.9; $\mathrm{Cl}$ 2,8.20).

\footnotetext{
${ }^{37}$ Ibid., 148.

${ }^{38}$ Adinolfi, “'Eikôn' nel De Iside et Osiride di Plutarco”, 126.

${ }^{39}$ Ibid.
} 
Na sua teologia, Paulo assume a gnôsis para enfatizar uma elevação do ser, na aproximação com o fazer de Jesus Cristo ( $F$ l 2,5). Ele exorta a buscar as coisas do alto, pois Cristo está sentado à destra de Deus; a pensar as coisas do alto, mesmo com os pés no chão firme da terra; a morrer para esse mundo, a fim de ressuscitar com Cristo ${ }^{40}$. Ele critica os espirituais por suas posiçóes fechadas de cunho alienante. Em outra pontuação, Paulo ironiza os "espirituais" que se tornam independentes, acreditando que pertencem a Cristo através da gnôsis (1Cor 1,12). Para o Apóstolo, essa postura não passa de uma ignorância e desconhecimento de Deus e de Jesus Cristo que gerou a comunidade cristá como uma sucessão de compromissos ${ }^{41}$.

$\mathrm{Na}$ reflexão sobre esse dualismo gnóstico, Paulo faz uso do termo eikôn (imagem - Rm 1,23; 1Cor 11,7; 2 Cor 4,4; Col 1,15) para afirmar que Cristo é a imagem do Deus invisível, mas que é a imagem perfeita de Deus, e é Filho de Deus $(\operatorname{Rm} 8,29)^{42}$.

\section{A educação}

A educação era o elemento primordial da formação helenística. Nessa cultura, ela significa um dos valores mais trabalhados, dentro do qual a pessoa podia expressar e desenvolver seus dotes e talentos. Mestres na arte, no lúdico, na política e na filosofia, os gregos consideram a educação um processo de orientação para a vida.

A paide,ia (educação) era a maior virtude para os cínicos; segundo Diógenes, a educaçáo é a graça para o jovem, consolo para o anciáo, abundância para o pobre e ornamento para o rico (Diógenes, Laertius, VI, 68). Monimus afirmava que era melhor ser cego do que não educado. Na educação entra um fator determinante: a pólis (cidade). Só na pólis se pode encontrar aquilo que abrange todas as esferas da vida espiritual e humana e determina de modo decisivo a sua estrutura. No período primitivo da cultura grega, todos os ramos da atividade espiritual brotam diretamente da raiz unitária da vida em comunidade. ${ }^{43}$

A pólis é o marco referencial de toda a vida na cultura grega. Paulo e seus companheiros não foram evangelizadores do campo, mas das cidades e, nas cidades, sempre buscaram todas as classes de pessoas, mas o destaque recai sobre as elites pensantes, pessoas influentes e agentes decisivos para a implantação do Evangelho ${ }^{44}$. Educar era

\footnotetext{
${ }^{40}$ Mazzarolo, Colossenses: Exegese e comentário, 88.

${ }^{41}$ Pagels, The Gnostic Paul. Gnostic Exegesis of the Pauline Letters, 60.

${ }^{42}$ Vanni, "Immagine di Dio Invisibile, Primogenito di ogni creazione", 102.

${ }^{43}$ Jaeger, Paideia, a formação do homem grego, 107.

${ }_{44}^{4}$ Meeks, Os primeiros cristãos urbanos, o mundo social do Apóstolo Paulo. O autor mostra em seu livro a influência e o alcance da pregaçáo de Paulo e seus companheiros nas grandes cidades da parte norte do Mar Mediterrâneo, desde a Palestina até Roma.
} 
a arte dos mestres, mas, para isso, estes precisavam de conhecimentos, condiçóes e capacidades de persuadir e fazer discípulos. $\mathrm{O}$ conhecimento do helenismo e do direito romano é fundamental para Paulo e seus colaboradores obterem êxito em sua missão nas grandes metrópoles de seu tempo.

Nessa perspectiva, pode-se concluir que todas as cartas de Paulo são didáticas e visam a instrução, mesmo em suas parêneses. Para que houvesse pregadores, Paulo afirmava que havia necessidade de instrutores: "Como, pois, invocarão aquele em quem não creram? E como crerão naquele de quem não ouviram? E como ouvirão, se não há quem pregue?” (Rm 10,14). Paulo segue os princípios dos grandes mestres gregos e forma uma escola de discípulos.

A educação helenística pesou muito na estrutura mental de Paulo. Na estrutura das cartas pode-se perceber sua formação literária. Analisando a Carta aos Gálatas, alguns autores encontram a seguinte estrutura: ${ }^{45}$

I. O preâmbulo $(1,1-5)$

II. $\mathrm{O}$ exordium ou introdução (1,6-11)

III. A narratio ou descrição dos fatos $(1,12-2,14)$

IV. A propositio ou tema (2,15-21)

V. A probatio ou prova $(3,1-4,31)$

VI. A parênese $(5,1-6,10)$

VII. O pós-escrito (6,11-18).

\section{A virtude}

Mesmo que com fins próprios, algumas correntes do helenismo evidenciavam a importância capital das virtudes éticas. A aretê (virtude) era um valor máximo para qualquer pessoa instruída como forma de moldar e desenvolver suas capacidades. Os valores e as qualidades de cada pessoa necessitavam de educação, orientação e desenvolvimento. A virtude era a estratégia dos sábios, os quais amavam o telós (o fim) e, de acordo com essa perspectiva viviam cada momento de sua história. Esse telós ou échaton fez parte da pedagogia cristã, especialmente em alguns blocos de discursos de Jesus (Mt 25; Mc 13,5-27; Lc 10,29-37) ${ }^{46}$.

O ser humano necessita de valores e virtudes para tornar nobre sua conduta e sua existência. Para os cínicos, a virtude é a arma que jamais pode ser abandonada ou perdida, e a sabedoria, a força maior que não pode ser jogada fora e menos ainda

\footnotetext{
${ }^{45}$ Hock, "Paulo e a educação greco-romana", 192.

${ }^{46}$ Mazzarolo, O Apóstolo Paulo, o grego o judeu e o cristão, 66.
} 
traída. A expressão virtude só aparece três vezes no Novo Testamento, na segunda Carta de Pedro (Fl 4,8; 2Pd 1,3.5). No entanto, a virtude como aperfeiçoamento e o conhecimento do bem dão suporte a outras reflexôes de Paulo ( $\mathrm{Rm}$ 7,7-25). Um dos grandes passos para o aprimoramento da vida era o conhecimento da justiça divina e das necessidades da conversão para o amor ( $R m$ 10,1-13; 12,3-21). No contexto da teologia paulina, a virtude é a passagem de um estágio de dependência do vício para a graça e a liberdade.

\section{A parusia paulina}

Em 1Cor 15,23, Paulo faz uso de um termo técnico na linguagem apocalíptica, que é a expressão parusia, já usada antes em 1 Ts 2,$19 ; 3,13 ; 4,15 ; 5,23$. Essa teologia se alicerçava sobre a expectativa da segunda vinda, ou seja, o retorno imediato após a ressurreição. $\mathrm{O}$ acento dessa apocalíptica do retorno de Jesus tem matizes helenísticos na sua sistematização ${ }^{47}$. Na verdade, Paulo crê na ressurreição e na parusia como a superação definitiva da morte e da limitação. Convencido disso, exclama: "Oh morte, onde está a tua vitória; oh morte, onde está o teu aguilhão?” (1Cor 15,55). A parusia aparece como um anseio de libertação definitiva (1Ts 4,13-18). Paulo afirma que a parusia seria imediata e que muitos cristáos não experimentariam a morte.

Isso se deve a que muitos cristãos vinham do templo pagão de Serafis, ao oeste de Tessalônica, onde duas importantes divindades egípcias eram cultuadas: Serafis e Ísis ${ }^{48}$. O que é fundamental, na escatologia paulina, são as exigências no aqui e agora, assumindo duas atitudes: (a) não esquematizar-se com as propostas dos tempos atuais deste mundo (Rm 12,2); (b) Transformar a própria mente para agir de modo agradável à vontade de Deus $(\mathrm{Rm} 12,2)$. O éschaton do Reino de Deus já está presente.

\section{A gnôsis em Corinto}

A partir da análise da terminologia de 1Cor 2,1-16, o uso de termos como sofía (sabedoria-1Cor 2,6), archontes (chefes - 1Cor 6,8) e teleios (a perfeição - 1Cor 2,6) revela uma ligação com o gnosticismo, mesmo que o conteúdo seja de ética e escatologia judaica. Isso pode mostrar como Paulo usa os elementos próximos do gnosticismo para inserir de modo aceitável a mensagem do Evangelho. Esse é um recurso literário possível somente a pessoas possuidoras de grande habilidade literária e teológica.

\footnotetext{
${ }^{47}$ Ibid., 89.

${ }^{48}$ Reisner, Paul's Early Period: Chronology, Mission Strategy, Theology, 383.
} 
Paulo demonstra uma capacidade de adaptação de um conteúdo semítico (os mistérios da revelação de Deus em Jesus Cristo) em linguagem e culturas diversas. É o resultado do domínio de diferentes culturas. Jamais o mistério da Revelação cristá teria chegado táo depressa e com tanta intensidade no helenismo se não fosse por essa capacidade de adequá-lo às estruturas de pensamento gnóstico-helenístico ${ }^{49}$.

${ }^{20}$ Procedi, para com os judeus, como judeu, a fim de ganhar os judeus; para os que vivem sob o regime da lei, como se eu mesmo assim vivesse, para ganhar os que vivem debaixo da lei, embora não esteja eu debaixo da lei. ${ }^{21}$ Aos sem lei, como se eu mesmo o fosse, ainda que não viva sem a lei de Deus, pois estou debaixo da lei de Cristo, para ganhar os que vivem fora do regime da lei. ${ }^{22} \mathrm{Fiz}-\mathrm{me}$ fraco para com os fracos, com o fim de ganhar os fracos. Fiz-me tudo para com todos, com o fim de, por todos os modos, salvar alguns. ${ }^{23}$ Tudo faço por causa do evangelho, com o fim de me tornar copartícipe com ele (1Cor 9,20-23).

Outro aspecto importante da gnose é a distinção entre pneyma (espírito) do homem e a sua psychê, (alma, mente) e entre o homem pneumatikós (espiritual) e psichykós (mental, intelectual). Esses detalhes revelam uma dualidade de substrato gnóstico, mesmo que esse dualismo entre alma e espírito raramente ocorra de forma pura. Igualmente, temos sempre uma tricotomia antropológica em que a alma está entre o corpo e o espírito. Muitos filósofos não aceitam essa postura gnóstica, afirmando que não há como fazer uma distinção concreta entre os dois elementos.

Dunn, no entanto, afirma que há uma distinção no mundo helenístico, pois psychê é o núcleo central da pessoa humana, indestrutível, isto é, não participa da decomposição do corpo e pneuma é compreendido como o espírito humano, mas com um significado incerto em Paulo ${ }^{50}$.

A sofia (sabedoria) da religiosidade de Corinto pode ser vista como uma terminologia clássica do gnosticismo. Ela é, igualmente, um elemento importante da religiosidade helenístico-judaica, presente na sabedoria de Salomão e em Fílon. Nisso constata-se o movimento de certa terminologia comum entre gnôsis, judaísmohelenístico e cristianismo, o que obriga a tomar qualquer um dos três corpos conceituais (helenismo; judaísmo; cristianismo) não como exclusivistas, mas dentro de certa propriedade conceitual, que sofre pequenas variações para poder estar na relação dos conteúdos.

Concernente à cristologia, percebe-se uma distinção substancial na posição de Paulo em relação ao gnosticismo. $\mathrm{O}$ texto de 1 Cor 8,6 pressupóe a pré-existência de Cristo no ato da criação. Da mesma forma seria o prólogo de João (Jo 1,1-6). Este texto de 1 Cor 8,6 pode ser colocado em paralelo com Pr 3,19; 8,30; Sb 7,22; 9,2-4.

\footnotetext{
${ }^{49}$ Fredrickson, "Paulo, as tribulaçōes e o sofrimento", 142-145.

${ }^{50}$ Dunn, A teologia do Apóstolo Paulo, 109.
} 
É perceptível que esses textos se contrapóem à postura tradicional do gnosticismo, uma vez que este desvaloriza a criação. Assim, igualmente, toda outra gama de tratados em torno de temas como o batismo, a experiência da redenção e da restauraçấo do ser humano em Cristo, como encontra-se em 2Cor 4,6, ali estão patenteados numa bela imagem da nova criação em Cristo. Em Rm 8,22, a criação inteira geme e sofre na expectativa da transformação, portanto, o cosmos está conectado com a vida humana. Em Cl 1,5-20 há também um paralelismo com a sabedoria, que revela um movimento descendente/ascendente do Redentor.

O papel do Redentor na criação é de uma participação positiva e não simplesmente de uma mudança de estágio. É agente ativo em ambos os casos, quer na criação, quer na Redenção. Finalmente em Hb 1,3, o autor aproxima Cristo à concepção da sabedoria-imagem de Deus.

O problema dos pneumatikoi (espirituais ou espiritualistas 1Cor 2,13-15), nos escritos paulinos, especialmente em 1Cor 14,1ss, traz algumas dificuldades para a sua interpretação. Em outras passagens, os pneumatikoi são associados com os teleiói (perfeitos, 1Cor 14,20; $\mathrm{Fl} 3,15 ; \mathrm{Cl} 4,12$ ). Paulo não era muito favorável a coisas que não tivessem um "cheiro" prático e antropologicamente verificável. Ele tem muita preocupação com as distorçôes da linguagem e da manipulação dos conceitos feitas por alguns, deixando outros em situaçóes comprometedoras. Esses sarkinoi (carnais 1Cor 3,1) podem ser chamados de népioi (infantis, imaturos) quanto ao conhecimento de Jesus Cristo, e o emprego da sua inteligência e de seus dons espirituais são mal usados e não frutificam na comunidade.

Paulo identifica Jesus Cristo como aquele que foi ressuscitado dentre os mortos $(\mathrm{Rm} 7,4)^{51}$. A maturidade espiritual está presente naqueles que compreendem a relação com a transcendência e produzem os frutos do Espírito.

Esse uso, quase exclusivo, do termo pneumatikoi na primeira Carta aos Coríntios, dado que na LXX ele não se encontra, e aparece pouco em outros textos (Ef 3,15), pode ser interpretado a partir da realidade da comunidade de Corinto. Aos Coríntios, Paulo fala igualmente da glossolalia, expressão vinculada aos dons do espírito, ligada às religióes mistéricas (1Cor 2,1.7; 4,1; 13,2; 14,2). Os mistérios, na cultura helenística, envolviam sempre elementos religiosos e políticos e estavam continuamente voltados aos planos divinos ${ }^{52}$.

Na teologia de Paulo, todo o mistério se esclarece no evento Jesus Cristo, pois ele é o plêrôma (plenitude) da lei, do amor e da justiça (cf. Rm 15,29; Gl 4,4; Ef 1,10).

\footnotetext{
${ }^{51}$ Carvalho. "O rosto de Cristo no epistolário paulino", 107.

${ }^{52}$ Bauer, "Mistêrion”, 1048.
} 
E nessa perspectiva da plenitude também pode-se ver a exaltação de Jesus como glorificação do Pai (Fl 2,9-11), que se aproxima muito do estilo da gnôsis helenística ${ }^{53}$. Na comparação entre o pensamento helenístico de Filon de Alexandria e Paulo, Sanders ${ }^{54}$ afirma que Paulo tem um pensamento mais elevado e distinto que o de Filon, o qual se comporta como um judeu-helenista.

Paulo, em muitos aspectos, se apresenta mais como helenista, especialmente, quando trata das tensões entre carne e espírito, sendo que a carne não é apenas o corpo, mas tudo o que se liga à matéria; de modo análogo, quando fala de Cristo como o verdadeiro mistério, nesse caso, se distancia do judaísmo que o apresentava como o Messias. Nesse aspecto, o helenismo era uma religiosidade de mistérios, complexa e muito influente nas classes superiores, através dos ritos de iniciaçâa ${ }^{55}$. Paulo usa de modo claro e explícito os mecanismos da linguagem helenística para apresentar aos seus ouvintes e leitores Cristo como mistério de Deus (1Cor 2,1.7; 4,4; Rm 11,25; 16,25).

\section{Conclusão}

A cultura helênica foi fundamental na missão de Paulo. Ele soube anunciar os mistérios da sabedoria divina e do Deus desconhecido (At 17,23), manifestados em Jesus Cristo, explorando os elementos da língua, da cultura e da religiosidade pagã. A fé inquebrantável em Jesus Cristo ressuscitado e a flexibilidade mental lhe asseguraram o grande êxito no anúncio do Evangelho. Em forma de síntese de nosso artigo sublinhamos os seguintes tópicos:

Paulo, como judeu, carrega sua bagagem antropológica judaica e uma fé muito sólida em Deus e na revelação de Jesus Cristo ressuscitado.

No confronto com o paganismo, Paulo aprende a flexibilidade dos seus paradigmas culturais judaicos para adaptar-se aos tempos, lugares e ambientes onde anunciava o Evangelho.

Ele absorve elementos das culturas grega e romana e aplica os recursos linguísticos para tornar o mistério do seu anúncio mais adequado aos ouvidos dos seus expectadores.

Centralizando toda a sua pregação em Jesus Cristo morto, crucificado e ressuscitado, ele sabe relativizar as coisas concernentes à cultura, tradição ou aos costumes familiares.

\footnotetext{
${ }^{53}$ Rudolph, La gnosi, 204-205.

${ }^{54}$ Sanders, Paolo e il giudaismo palestinese. Studio comparativo su modelli di religione, 760.

55 Tripolitis, Religions of the Hellenistic-Roman Age, 17.
} 
Ele encontra na tradição helenística os alicerces da teoria da filiação em Deus, por meio do Espírito.

O cristianismo é devedor do judaísmo no caminho da fé, do monoteísmo e da revelação de Deus libertador. O cristianismo é devedor do helenismo enquanto aprende a abertura, a acolhida e a organização das comunidades. No helenismo, Zeus concorria com o Deus cristáo, como pai supremo. Na pessoa de Jesus Cristo, os cristãos receberam o Espírito da filiação, por meio do qual clamam $A b b a ́ a(R m ~ 8,15)$. O cristianismo é devedor do helenismo na sua forma de abertura, de integração social, de visão de comunidade e da ruptura de paradigmas arcaicos. É nesses novos parâmetros que Paulo busca alicerçar a formação das novas comunidades cristãs, integrando classes e categorias diferentes, sem preconceitos (Gl 3,28; $\mathrm{Rm} \mathrm{10,12;} \mathrm{Cl} \mathrm{3,11).}$

\section{Referências bibliográficas}

Adinolfi, Marco. “'Eikôn' nel De Iside et Osiride di Plutarco”. In La Cristologia in San Paolo. Atti dela XXIII Setimana Biblica, Associazione Biblica Italiana, 115-129. Brescia: Paideia, 1976.

Bauer, Walter."Agôn”. In Wöerterbuch zum Neuen Testament, por W. Bauer, 28-29. Berlin-New York: W. de Gruynter, 1971.

. "Gnôsis". In Wöerterbuch zum Neuen Testament, por W. Bauer, 324. BerlinNew York: W. de Gruynter, 1971.

. "Mistêrion". In Wöerterbuch zum Neuen Testament, por W. Bauer, 1048. Berlin-New York: W. de Gruynter, 1971.

. "Sôtêr". In Wöerterbuch zum Neuen Testament, por W. Bauer, 1585. BerlinNew York: W. de Gruynter, 1971.

Betz, Hans Dieter. Hellenismus und Urchristentum. Tübingen: J. C. B. Mohr, 1990.

Benoit, Pierre. "Genese et évolution de la pensée paulinienne”. In Paul de Tarse Apôtre du notre Temps, editado por Lorenzo de Lorenzi, 75-100. Rome: Abbaye de S. Paul H. L. M., 1979.

Bill, A. "La littérature religieuse hellénistique et les religions des mystères d'après Reitzenstein”. Revue d'histoire et de philosophie religieuse 5 (1923) : 443-457.

Carvalho, José Carlos. “O rosto de Cristo no epistolário paulino”. São Paulo Apóstolo da Palavra. Bíblica 17 (2008): 99-131.

Chevalier, Jean, e Alain Gheerbrant. Dicionário de simbolos: mitos, sonhos, costumes, gestos, formas, figuras, cores, números (8. ${ }^{\mathrm{a}} \mathrm{ed}$.). Rio de Janeiro: José Olympio, 1994. 
Cicero. Oraçôes. Vol. II. Rio de Janeiro: W. M. Jackson Inc. Editores, 1952.

Corssen, Paul. "Über Begriff und Wesen des Hellenismus". En Zeitschrift für Neutestamentliche Wissenschaft und die Kunde des Urchristentums 1 (1908): 81-95.

Delcourt, Marie. Légendes et cultes de héros en Grèce. Paris: Presses Universitaires, 1942.

Dunn, James D. G. A teologia do Apóstolo Paulo. São Paulo: Paulus, 2003.

Fredrickson, David E. "Paulo, as tribulações e o sofrimento". In Paulo no mundo greco-romano. Um compêndio, organizado por J. Paul Sampley, 147-170. São Paulo: Paulus, 2008.

Grech, Prosper. "L'Inno cristologico di Col 1 e la gnose". In La cristologia in San Paolo. Atti dela XXIII Setimana Biblica, Associazione Biblica Italiana, 57-80. Brescia: Paideia, 1976.

Hadjifoti, Litsa. Apóstol Pablo: su vida y su obra. Atenas: Editorial M. Toubis S.A., 2007.

Hock, Ronald. "Paulo e a educação greco-romana”. In Paulo no mundo greco-romano. Um compêndio, organizado por J. Paul Sampley, 171-221. São Paulo: Paulus, 2008.

Jaeger, Werner. Paideia, a formação do homem grego. São Paulo: Martins Fontes, 1995.

Kittel, Gerhard. Die Religionsgeschichte und das Urchristentum. Tübingen: Vandenhoeck \& Ruprecht, 1931.

Krentz, E. "Paulo, os jogos e a milícia". In Paulo no mundo greco-romano. Um compêndio, organizado por J. Paul Sampley, 303-335. São Paulo: Paulus, 2008.

Lalande, André. "Gnose". In Vocabulário técnico e crítico da filosofia, por A. Lalande, 447-449. São Paulo: Martins Fontes, 1999.

Mazzarolo, Isidoro. Carta de Paulo aos Romanos. Educar para a maturidade e o amor. Rio de Janeiro: Mazzarolo Editor, 2006.

. Colossenses: Exegese e comentário. Rio de Janeiro: Mazzarolo Editor, 2012.

. O Apóstolo Paulo, o grego, o judeu e o cristão. Rio de Janeiro: Mazzarolo Editor, 2011.

Meeks, Wayne. Os primeiros cristãos urbanos, o mundo social do Apóstolo Paulo. São Paulo: Paulinas, 1992.

Murphy-O'Connor, Jerome. Jesus e Paulo, vidas paralelas (2. ${ }^{a}$ ed.). São Paulo: Paulinas, 2009. 
Odelain, Olivier, e Raymond Séguineau. "Paul, Paulus". In Dictionnaire des noms propres de la Bible, por de O. Odelain, R. Séguineau e R. Tournay, 289-291. Paris: Du Cerf, 1978.

Pagels, Eliane. The Gnostic Paul. Gnostic Exegesis of the Pauline Letters. Harrisburg (PA): Trinity Press International, 1992.

Penna, Romano. "Paulo de Tarso e os componentes gregos do seu pensamento". Atualidade teológica 31 (2009): 55-91.

. "L'Evangile de la paix". In Paul de Tarse apôtre du notre temps, editado por Lorenzo de Lorenzi, 175-199. Rome: Abbaye de S. Paul H. L. M., 1979.

Riesner, Reiner. Paul's Early Period: Chronology, Mission Strategy, Theology. Grand Rapids (MI): Willian B. Eerdmans Publishing Company, 1998.

Rudolph, Kurt. La gnosi. Brescia: Paideia, 2000.

Sanders, Ed Parish. Paolo e il giudaismo palestinese. Studio comparativo su modelli di religione. Brescia: Paideia, 1986.

Schmitz, Ernst Dieter. "Conhecimento". In Dicionário internacional de teologia: Novo Testamento. Vol. I, organizado por Lothar Coenen e Colin Brown, 392-405. São Paulo: Vida Nova, 2000.

Tripolitis, Antonía. Religions of the Hellenistic-Roman Age. Grand Rapids (MI): W. B. Eerdmans Publishing Company, 2002.

Turbessi, Giuseppe. "L'Apôtre Paul, 'Homme de Dieu”. In Paul de Tarse apôtre du notre temps, editado por Lorenzo de Lorenzi, 100-162. Rome: Abbaye de S. Paul H. L. M., 1979.

Vanni, Ugo. "Immagine di Dio invisibile, Primogenito di ogni creazione". In $\mathrm{La}$ cristologia in San Paolo. Atti dela XXIII Setimana Biblica, Associazione Biblica Italiana, 97-113. Brescia: Paideia, 1976.

Von Dubschütz, E. “Christianity and Hellenism”. Journal of Biblical Literature 33 (1914): 245-265.

Walters, James C. "Paulo, a adoção e a herança”. In Paulo no mundo greco-romano. Um compêndio, organizado por J. Paul Sampley, 25-56. São Paulo: Paulus, 2008. 